\title{
Exposure risk to carbonyl compounds and furfuryl alcohol through the consumption of sparkling wines
}

\section{Gabriela Pelizza Peterle ${ }^{1}$ Karolina Cardoso Hernandes ${ }^{1}$ Luana Schmidt $^{1}$ Júlia Barreto Hoffmann Maciel $^{1}$ Claudia Alcaraz Zini ${ }^{2}$ Juliane Elisa Welke ${ }^{{ }^{*}}$}

${ }^{1}$ Instituto de Ciência e Tecnologia de Alimentos (ICTA), Universidade Federal do Rio Grande do Sul (UFRGS), 91501970, Porto Alegre, RS, Brasil. E-mail:juliane.welke@ufrgs.br."Corresponding author.

${ }^{2}$ Instituto de Química (IQ), Universidade Federal do Rio Grande do Sul (UFRGS), Porto Alegre, RS, Brasil.

ABSTRACT: The goals of this study were to verify the occurrence of furfuryl alcohol (FA) and carbonyl compounds (acetaldehyde, acrolein, ethyl carbamate (EC), formaldehyde and furfural) in sparkling wines and to evaluate, for the first time, whether the consumption of the samples under study could represent risk to consumers health. These compounds are electrophilic; and therefore, may covalently bind to DNA, which may result in mutagenicity. EC and formaldehyde were present at low levels $\left(<1 \mu \mathrm{g} \mathrm{L}^{-1}\right)$ in all samples. Acetaldehyde, furfural and acrolein were also found in low levels $\left(<1.5,1.4\right.$ and $1.0 \mu \mathrm{g} \mathrm{L}^{-1}$, respectively) in 57,71 and $76 \%$ of samples. In the other samples, levels of acetaldehyde, furfural and acrolein ranged from 5.2 to 54.8, 10.5 to 41.0 and 20.3 to $36.7 \mu \mathrm{g} \mathrm{L}^{-1}$, respectively. Furfuryl alcohol was also reported in all samples in levels from 10.4 to $33.5 \mu \mathrm{g} \mathrm{L}^{-1}$. Acrolein was the only compound reported at levels sufficient to represent risk to health, which occurred in $24 \%$ of the samples. A study focused on the origin of acrolein deserves attention, investigating the influence of the concentration of precursors and the role of fermentation in the formation of this aldehyde, besides the evaluation of possible environmental contamination of grapes during cultivation.

Key words: risk assessment, sparkling wine consumption, carbonyl compounds, furfuryl alcohol.

Risco da exposição a compostos carbonílicos e álcool furfurílico através do consumo de espumantes

RESUMO: Os objetivos deste estudo foram verificar a ocorrência de álcool furfurílico (FA) e compostos carbonílicos (acetaldeido, acroleína, carbamato de etila (CE), formaldeído e furfural) em espumantes e avaliar, pela primeira vez, se o consumo das amostras em estudo poderia representar risco para a saúde do consumidor. Esses compostos são eletrofilicos e, portanto, podem se ligar covalentemente ao DNA, o que pode resultar em mutagenicidade. CE e formaldeído foram encontrados em baixos níveis $(<1 \mu \mathrm{g} / L)$ em todas as amostras. Acetaldeido, furfural e acroleina também foram encontrados em baixos niveis $\left(<1,5 ; 1,4\right.$ e 1,0 $\mu \mathrm{g} L^{-1}$, respectivamente) em 57,71 e $76 \%$ das amostras. Nas demais

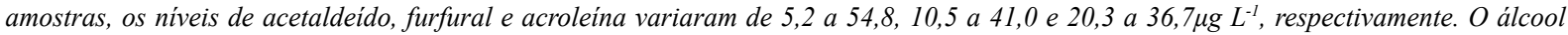
furfurílico também foi encontrado em todas as amostras em níveis de 10,4 a 33,5 $\mu \mathrm{g} \mathrm{L}^{-1}$. A acroleina foi o único composto encontrado em níveis suficientes para representar risco à saúde, que ocorreu em $24 \%$ das amostras. Uma avaliação focada na origem da acroleína merece atenção, investigando a influência da concentração dos precursores e o papel da fermentação na formação do aldeído, além da avaliação da possível contaminação ambiental das uvas durante o cultivo.

Palavras-chave: avaliação de risco, consumo de espumante, compostos carbonílicos, álcool furfurílico.

Furfuryl alcohol (FA) and carbonyl compounds, including acetaldehyde, acrolein, formaldehyde, furfural and ethyl carbamate may form adducts with the DNA due to their electrophilic nature. As consequence, the exposure to furfuryl alcohol (SACHSE et al., 2016), acetaldehyde (ERIKSSON, 2015) and ethyl carbamate (LIU et al., 2017), for example, may increase the risk of cancer in some parts of the human organism, including liver and kidneys. Furthermore, these compounds may be associated with some particular toxic effects, such the relation between formaldehyde and arthritis (OSMAN et al., 2017) and acrolein that play an important role in Parkinson's (AMBAW et al., 2018) and Alzheimer's diseases (BURCHAM, 2017). Furfural toxicity still needs to be better studied, but it is suspected of being a mutagen and might be associated with liver neoplasms (hepatocellular adenomas or carcinomas) (ARTS et al., 2004).

These compounds may be formed from sugars and amino acids, especially during fermentation (RIBÉREAU-GAYON et al., 2006). In addition, acrolein and furfural may be released to the environment and contaminate grapes during 
incomplete combustion processes (petrochemical fuels, wood, cigarette smoking among others) (KENNISON et al., 2007; BURCHAM, 2017). In a previous study, the occurrence of carbonyl compounds (formaldehyde, acetaldehyde, acrolein, furfural and EC) was reported in all stages of vinification, including grapes and the respective wines (FERREIRA et al., 2018). However, toxic levels were reduced throughout Merlot vinification and only the exposure to acrolein revealed represent risk to consumer's health. In another approach, LAGO et al. (2017) verified that the advancement of ripeness degree and increasing grape maceration time seems to result in higher concentrations of these carbonyl compounds in Syrah wines. Regarding the consumption of these wines, the exposure to acrolein and ethyl carbamate could pose risk to consumer health.

The occurrence of FA and carbonyl compounds (acetaldehyde, acrolein, EC, formaldehyde and furfural) was studied in this research with the objective of verifying, for the first time, the risk of exposure to these compounds through consumption of sparkling wines. Sparkling wines from 21 different wineries of Rio Grande do Sul State, Brazil, were evaluated. Samples were analyzed in triplicate and total acidity, $\mathrm{pH}$ and alcohol content were verified according the ASSOCIATION OF OFFICIAL AGRICULTURAL CHEMISTIS (1995), since these parameters can influence the efficiency of HS-SPME (FERREIRA et al., 2019). The median values of acidity (108meq L-1), $\mathrm{pH}$ (3.1) and alcohol $(12 \%)$ of samples were used in the preparation of the model solution of sparkling wine to perform the calibration curves of toxic compounds. This approach was followed to minimize matrix effects in the analysis quantification.

The estimated daily intake (EDI) and characterization of the exposure risk were obtained following the protocols of the World Health Organization (WHO, 2010), as reported in previous studies (LAGO et al., 2017; FERREIRA et al., 2018; DACHERY et al. 2017). The EDI was expressed in $\mu \mathrm{g} \mathrm{kg}^{-1}$ of body weight (BW) per day and calculated as follows:

$$
E D I=\frac{\begin{array}{c}
\text { concentration of toxic compound }\left(\mu g \mathrm{~mL}^{-1}\right) \\
\text { sparkling wine consumption } \left.\left(m L \text { day }^{-1}\right)\right]
\end{array}}{\text { body weight }(\mathrm{kg})}
$$

The concentration of toxic compounds was obtained through headspace solid phase microextraction associated with gas chromatography with quadrupole mass spectrometric detection in selected-ion monitoring mode (HS-SPME-GC/
qMS-SIM) according previous validated method (FERREIRA et al., 2019).

The consumption of sparkling wine used in the calculation of EDI was $300 \mathrm{~mL}$, considering that: (i) the maximum daily alcohol intake should not exceed $30 \mathrm{~g}$ (equivalent to $39 \mathrm{~mL}$ of ethanol), as established by the Health Agencies of several countries, including the United States of America, France, Macedonia, New Zealand, Romania, Switzerland, Uruguay and released by the International Alliance for Responsible Drinking (IARD, 2018), and that (ii) the evaluated sparkling wines presented ethanol content between 11.5 and $12.5 \%(\mathrm{v} / \mathrm{v})$. Furthermore, VÁZQUEZAGELL et al. (2007) reported that daily consumption of $300 \mathrm{~mL}$ of Chardonnay sparkling wine may prevent atherosclerosis due to its polyphenol content.

The Brazilian average weight of $66.5 \mathrm{~kg}$, according to Analysis of Personal Food Consumption done by Brazilian government (IBGE, 2011), was used in the EDI calculation.

Acetaldehyde, acrolein, formaldehyde and ethyl carbamate are genotoxic compounds and margin of exposure (MOE) must be used in risk characterization considering the benchmark dose lower confidence limit (BMDL10) as toxicological parameter in the in the calculation:

$$
M O E=\frac{B M D L 10\left(\mu g \mathrm{~kg}^{-1} B W d a y^{-1}\right)}{E D I\left(\mu g \mathrm{~kg}^{-1} B W d a y^{-1}\right)}
$$

BMDL10 corresponds to the lowest limit of the $95 \%$ confidence interval of the dose required to give a $10 \%$ increase in the occurrence of a toxic effect compared to the control. BMDL10 values were: $56,0.36,0.25$ and $28 \mathrm{mg} \mathrm{kg}^{-1}$ of body weight per day were used for acetaldehyde (LACHENMEIER et al., 2009), acrolein (ATSDR, 2007), EC (SCHLATTER et al., 2010) and formaldehyde (MONAKHOVA et al., 2012), respectively, as already mentioned in a previous study (FERREIRA et al. 2018).

MOE values below 10,000 indicated that the compound poses a potential health risk (WHO, 2010). In contrast, furfural and furfuryl alcohol are non-genotoxic compounds; and therefore, has a safe ingestion parameter set by JECFA (acceptable summative daily intake (ADI) of $500 \mu \mathrm{g} \mathrm{kg}^{-1} \mathrm{BW}$ ) (JECFA, 2000). Risk characterization for these two furan-containing compounds was carried out comparing the EDI with its ADI, where risk may exist if the estimated intake exceeds the ADI.

Carbonyl compounds and furfuryl alcohol were reported in all samples. Table 1 presents the levels, EDI and MOE of these compound found in sparkling wines under study. EC and formaldehyde were not included in table 1 , as these compounds were 
found at low levels in all samples (not quantifiable since these values were between the LOD and LOQ of the method, 0.4 and $1 \mu \mathrm{g} \mathrm{L} \mathrm{L}^{-1}$, respectively for both compounds), indicating no risk to consumer health. The occurrence of these compounds was reported for the first time in sparkling wines in the present study. The same exposure risk assessment approach adopted for the samples under study was used to verify if the levels of these compounds reported in the literature would pose a risk to consumers' health. In still wines, EC was reported, for example, in samples from China (13.7 $\left.\mu \mathrm{g} \mathrm{L}^{-1}\right)$ (ZHANG et al. 2014) and Portugal $\left(54.1 \mu \mathrm{g} \mathrm{L}^{-1}\right)$ (PERESTRELO et al. 2010), which exposure would result in MOE values of 4167 and 1042, respectively; and therefore, with health risk potential according to the threshold of World Health Organization (MOE<10,000) (WHO, 2010).
Formaldehyde was found in wines from South Korea and Germany at average levels of $40.9 \mu \mathrm{g} \mathrm{L}^{-1}$ (JEONG et al. 2015) and $130 \mu \mathrm{g} \mathrm{L}^{-1}$ (JENDRAL et al. 2011), resulting in MOE values of 155,556 and 47,457, respectively; i.e., with no potential for risk to health.

Acetaldehyde, furfural and acrolein were also reported at low levels (concentrations lower than LOQ of the method: $1.5,1.4$ and $1.0 \mu \mathrm{g} \mathrm{L}^{-1}$ and higher than LOD: $0.8 ; 0.5$ and $0.7 \mu \mathrm{g} / \mathrm{Lin} 57,71$ and $76 \%$ of samples, respectively), which do not pose a health risk. In the other samples, the levels of acetaldehyde and furfural ranged from 5.2 to 50.5 and 10.5 to $41 \mu \mathrm{g} \mathrm{L}^{-1}$, respectively (Table 1 ). Levels of these compounds were used for the calculation of the possible exposure, resulting in low EDI ranging from 0.023 to 0.247 and 0.047 to $0.185 \mu \mathrm{g} \mathrm{kg}^{-1}$ of BW for acetaldehyde and furfural, respectively. Since

Table 1 - Levels \pm standard deviation $\left(\mu \mathrm{g} \mathrm{L} \mathrm{L}^{-1}\right.$ ), estimated daily intake (EDI, $\mu \mathrm{g} \mathrm{kg}^{-1}$ of body weight) and margin of exposure (MOE, calculated only for genotoxic compounds including acetaldehyde and acrolein) of the toxic compounds reported in the sparkling wines analyzed by HS-SPME-GC/MS-SIM. EC and formaldehyde were not included in the Table, since these compounds were found at levels between the LOD and LOQ of the method $\left(0.4\right.$ and $1 \mu \mathrm{g} \mathrm{L}{ }^{-1}$, respectively, for both compounds) in all samples.

\begin{tabular}{|c|c|c|c|c|c|c|c|c|c|c|}
\hline \multirow[b]{2}{*}{ N. ${ }^{a}$} & \multicolumn{3}{|c|}{-------------Acetaldehyde------------- } & \multicolumn{3}{|c|}{-----------------Acrolein--------------- } & \multicolumn{2}{|c|}{---------Furfural-------- } & \multicolumn{2}{|c|}{-----Furfuryl alcohol---- } \\
\hline & Level & EDI & MOE & Level & EDI & MOE & Level & EDI & Level & EDI \\
\hline 1 & $<\mathrm{LOQ}$ & $<0.007$ & $>8331096$ & $<\mathrm{LOQ}$ & $<0.009$ & $>40101$ & $<\mathrm{LOQ}$ & $<0.006$ & $15.8 \pm 2.0$ & 0.071 \\
\hline 2 & $<$ LOQ & $<0.007$ & $>8331096$ & $<\mathrm{LOQ}$ & $<0.009$ & $>40101$ & $<\mathrm{LOQ}$ & $<0.006$ & $11.1 \pm 0.1$ & 0.050 \\
\hline 3 & $<\mathrm{LOQ}$ & $<0.007$ & $>8331096$ & $<\mathrm{LOQ}$ & $<0.009$ & $>40101$ & $12.9 \pm 0.1$ & 0.058 & $42 \pm 3.9$ & 0.189 \\
\hline 4 & $<\mathrm{LOQ}$ & $<0.007$ & $>8331096$ & $<\mathrm{LOQ}$ & $<0.009$ & $>40101$ & $<\mathrm{LOQ}$ & $<0.006$ & $14.4 \pm 0.8$ & 0.065 \\
\hline 5 & $12.4 \pm 0.0$ & 0.056 & 1001075 & $<\mathrm{LOQ}$ & $<0.009$ & $>40101$ & $<\mathrm{LOQ}$ & $<0.006$ & $13.7 \pm 1.4$ & 0.062 \\
\hline 6 & $50.5 \pm 1.7$ & 0.228 & 245809 & $33.1 \pm 1.7$ & 0.149 & 2411 & $15.6 \pm 3.3$ & 0.070 & $15.8 \pm 1.7$ & 0.071 \\
\hline 7 & $<\mathrm{LOQ}$ & $<0.007$ & $>8331096$ & $<\mathrm{LOQ}$ & $<0.009$ & $>40101$ & $<\mathrm{LOQ}$ & $<0.006$ & $14.4 \pm 1.7$ & 0.065 \\
\hline 8 & $37.9 \pm 3.7$ & 0.171 & 327529 & $33.4 \pm 0.3$ & 0.151 & 2389 & $41.0 \pm 0.4$ & 0.185 & $13.9 \pm 0.8$ & 0.063 \\
\hline 9 & $<\mathrm{LOQ}$ & $<0.007$ & $>8331096$ & $<\mathrm{LOQ}$ & $<0.009$ & $>40101$ & $<\mathrm{LOQ}$ & $<0.006$ & $11.9 \pm 0.7$ & 0.054 \\
\hline 10 & $31.1 \pm 0.8$ & 0.140 & 399143 & $<\mathrm{LOQ}$ & $<0.009$ & $>40101$ & $32.1 \pm 0.3$ & 0.145 & $17.9 \pm 0.5$ & 0.081 \\
\hline 11 & $<\mathrm{LOQ}$ & $<0.007$ & $>8331096$ & $<\mathrm{LOQ}$ & $<0.009$ & $>40101$ & $<\mathrm{LOQ}$ & $<0.006$ & $13.4 \pm 0.3$ & 0.060 \\
\hline 12 & $<$ LOQ & $<0.007$ & $>8331096$ & $<\mathrm{LOQ}$ & $<0.009$ & $>40101$ & $<$ LOQ & $<0.006$ & $16.2 \pm 0.6$ & 0.073 \\
\hline 13 & $<$ LOQ & $<0.007$ & $>8331096$ & $<\mathrm{LOQ}$ & $<0.009$ & $>40101$ & $<\mathrm{LOQ}$ & $<0.006$ & $13.6 \pm 0.2$ & 0.061 \\
\hline 14 & $30.5 \pm 8.7$ & 0.138 & 406995 & $28 \pm 1.8$ & 0.126 & 2850 & $14.4 \pm 3.0$ & 0.065 & $15.5 \pm 0.6$ & 0.070 \\
\hline 15 & $<\mathrm{LOQ}$ & $<0.007$ & $>8331096$ & $<\mathrm{LOQ}$ & $<0.009$ & $>40101$ & $<\mathrm{LOQ}$ & $<0.006$ & $21.9 \pm 1.7$ & 0.099 \\
\hline 16 & $5.2 \pm 1.6$ & 0.023 & 2387179 & $<$ LOQ & $<0.009$ & $>40101$ & $<$ LOQ & $<0.006$ & $17.8 \pm 0.3$ & 0.080 \\
\hline 17 & $15.1 \pm 4.0$ & 0.068 & 822075 & $<\mathrm{LOQ}$ & $<0.009$ & $>40101$ & $<\mathrm{LOQ}$ & $<0.006$ & $14.2 \pm 1.0$ & 0.064 \\
\hline 18 & $54.8 \pm 8.9$ & 0.247 & 226521 & $36.7 \pm 3.0$ & 0.166 & 2174 & $10.5 \pm 3.4$ & 0.047 & $20.3 \pm 3.4$ & 0.092 \\
\hline 19 & $<\mathrm{LOQ}$ & $<0.007$ & $>8331096$ & $20.3 \pm 2.4$ & 0.092 & 3931 & $<\mathrm{LOQ}$ & $<0.006$ & $22.5 \pm 2.9$ & 0.102 \\
\hline 20 & $<\mathrm{LOQ}$ & $<0.007$ & $>8331096$ & $<\mathrm{LOQ}$ & $<0.009$ & $>40101$ & $<$ LOQ & $<0.006$ & $10.4 \pm 1.7$ & 0.047 \\
\hline 21 & $10.2 \pm 1.6$ & 0.046 & 1216993 & $<\mathrm{LOQ}$ & $<0.009$ & $>40101$ & $<$ LOQ & $<0.006$ & $33.5 \pm 4.0$ & 0.151 \\
\hline
\end{tabular}

a Sample number.

LOQ: limit of quantification of HS-SPME-GC/MS-SIM method for acetaldehyde, furfural and acrolein was $1.5,1.4$ and $1.0 \mu \mathrm{g} \mathrm{L}^{-1}$, respectively, according to the validation procedure previously reported by Ferreira et al. (2019).

Ciência Rural, v.49, n.3, 2019. 
acetaldehyde is genotoxic, the MOE was used to characterize the risk, which presented values higher than 10,000 (ranging from 2,387,179 to 226,521 , as shown in table 1), indicating that the exposure to this aldehyde does not pose a health risk.

In the case of furfural (non-genotoxic), the EDI has also indicated no health risk, since EDI was lower than the ADI established by JECFA (2000). The same was verified for furfuryl alcohol found at levels from 10.4 to $42 \mu \mathrm{g} \mathrm{L} \mathrm{L}^{-1}$, which correspond to EDI of 0.047 to $0.189 \mu \mathrm{g} \mathrm{kg}^{-1}$ of $\mathrm{BW}$, respectively; and therefore, also lower than the ADI $\left(500 \mu \mathrm{g} \mathrm{kg}^{-1}\right.$ of $\mathrm{BW})$. Regarding the occurrence of these compounds reported in literature, only acetaldehyde was previously verified in sparkling wines (WEBBER et al., 2017), which levels was higher (up 60mg L-1, which indicate risk for consumers' health) than those reported in this study.

Levels (20.3 to $\left.36.7 \mu \mathrm{g} \mathrm{L}^{-1}\right)$ and EDI $(0.092$ to $166 \mu \mathrm{g} \mathrm{kg}^{-1}$ of BW) of acrolein found in $24 \%$ of the samples under study were sufficient to represent risk to health (MOE values between 3931 and 2174, respectively; i.e, lower than WHO threshold $(10,000)$ (WHO, 2010). This aldehyde was reported for the first time in sparkling wine and has rarely been evaluated in still wines in the literature. In still wines from South African, BAUER et al. (2012) have not detected acrolein and in German wines. KÄCHELE et al. (2015) reported acrolein in still wines at lower levels $\left(0.7 \mu \mathrm{g} \mathrm{L}^{-1}\right)$ than those verified in this study; and therefore without potential to cause health risk (MOE: 120,000 obtained using the same exposure approach adopted for the sparkling wines under study).

Levels of acetaldehyde, EC, formaldehyde, furfural and furfuryl alcohol reported in all sparkling wines do not pose a risk to the health of consumers. However, the occurrence of acrolein deserves attention. This compound was the only whose exposure indicates concern due to the levels detected and its possibility of reacting with the biological nucleophilic targets such as proteins, RNA and DNA, causing cellular dysfunction and/or mutagenicity. In our previous studies, acrolein was found in still wines elaborated using Syrah grapes from São Francisco Valley (LAGO et al., 2017) and Merlot from Campanha Gaúcha (FERREIRA et al., 2018) in sufficient quantities to result risk to human health. This compound was also present in grapes used to winemaking (FERREIRA et al., 2019). Therefore, the environmental contamination of grapes with acrolein due to incomplete combustion processes (petrochemical fuels and wood) or photo oxidation of hydrocarbon found in air may be related the occurrence of this aldehyde in wines.
The role of precursors, fermentation, type of sparkling and storage in the acrolein levels should be elucidated to predict strategies focused on reducing the occurrence of this compound. In addition, it is important to mention that the evaluation of levels of carbonyl compounds and furfuryl alcohol, as well as the monitoring of levels of ochratoxin A and pesticide residues can be important tools for the quality control of wines.

\section{ACKNOWLEDGEMENTS}

This study was funded by National Council of Technological and Scientific Development (Conselho Nacional de Desenvolvimento Científico e Tecnológico (CNPq), CNPq project $\mathrm{Pq}$ 425755/2016-9), the Coordination for the Improvement of Higher Education Personnel, Coordenação de Aperfeiçoamento de Pessoal de Nível Superior (CAPES) and Research Support Foundation of Rio Grande do Sul (Fundação de Amparo à Pesquisa do Estado do Rio Grande do Sul (FAPERGS), Edital Pesquisador Gaúcho, Project 1995-2551/13-7).

\section{DECLARATION OF CONFLICT OF INTERESTS}

The authors declare no conflict of interest. The founding sponsors had no role in the design of the study; in the collection, analyses, or interpretation of data; in the writing of the manuscript, and in the decision to publish the results.

\section{AUTHORS' CONTRIBUTIONS}

The authors contributed equally to the manuscript.

\section{REFERENCES}

AMBAW, A. et al. Acrolein-mediated neuronal cell death and alpha-synuclein aggregation: Implications for Parkinson's disease. Molecular and Cellular Neuroscience, v.88, p.70-82, 2018. Available from: <http://dx.doi.org/10.1016/j.mcn.2018.01.006>. Accessed: May, 14, 2018. doi: 10.1016/j.mcn.2018.01.006.

ARTS, J.H.E., et al. Subacute (28-day) toxicity of furfural in Fischer 344 rats: A comparison of the oral and inhalation route. Food and Chemical Toxicology, v.42, p.1389-1399, 2004. Available from: $<$ https://doi.org/10.1016/j.fct.2004.03.014>. Accessed: Jun. 12, 2018. doi: 10.1016/j.fct.2004.03.014

ASSOCIATION OF OFFICIAL AGRICULTURAL CHEMISTIS. Methods of analysis of AOAC International, 16.ed. Arlington: AOAC, 1995. p.777-801 Available from: <https://law.resource.org/pub/ us/cfr/ibr/002/aoac.methods.1.1990.pdf>. Accessed: May, 14, 2018.

ATSDR. Agency for toxic substances and disease registry, toxicological profile for acrolein. U.S. Department of Health and Human Services, 2007; Available from: <https://www.atsdr.cdc.gov/ toxprofiles/tp.asp?id=557\&tid=102>. Accessed: Nov. 27, 2018.

BAUER,R.; KOSSMANN,J. Influence ofenvironmentalparameters on production of the acrolein precursor 3-hydroxypropionaldehyde by Lactobacillus reuteri DSMZ 20016 and its accumulation 
by wine lactobacilli, International Journal of Food Microbiology, v.137, n.28, 2010. Available from: $<$ https://doi. org/10.1016/j.ijfoodmicro.2009.10.012>. Accessed: Jul. 12, 2018. doi: 10.1016/j.ijfoodmicro.2009.10.012.

BURCHAM, P.C. Acrolein and human disease: untangling the knotty exposure scenarios accompanying several diverse disorders. Chemical Research in Toxicology, v.30, p.145-161, 2017. Available from: <https://pubs.acs.org/doi/full/10.1021/acs. chemrestox.6b00310> Accessed: May, 14, 2018. doi: 10.1021/acs. chemrestox.6b00310

DACHERY, B. et al. Exposure risk assessment to ochratoxin A through consumption of juice and wine considering the effect of steam extraction time and vinification stages. Food and Chemical Toxicology, v.109, p.237-244, 2017. Available from: <http:// dx.doi.org/10.1016/j.fct.2017.09.013>. Accessed: Jul. 12, 2018. doi: 10.1016/j.fct.2017.09.013.

ERIKSSON, C. J. P. Genetic-epidemiological evidence for the role of acetaldehyde in cancers related to alcohol drinking. In V. Vasiliou, S. Zakhari, H. Seitz, J. Hoek (Eds.), Biological Basis of Alcohol-Induced Cancer. New york: Springer. (2015). Available from: $<$ https://link. springer.com/chapter/10.1007\%2F978-3-319-09614-8 3>. Accessed: May, 14, 2018. doi: 10.1007/978-3-319-09614-8_3.

FERREIRA, D.C. et al. Carbonyl compounds in different stages of vinification and exposure risk assessment through Merlot wine consumption. Food Additives and Contaminants, v.35, p. 2315-2331, 2018. Available from: <http://dx.doi.org/10.1080/19440049.2018.153 9530> Accessed: Jan. 7, 2019. doi: 10.1080/19440049.2018.1539530

FERREIRA, D.C. et al. Development of a method for determination of target toxic carbonyl compounds in must and wine using HSSPME-GC/MS-SIM after preliminary GC $\times$ GC/TOFMS analyses. Food Analytical Methods, v.12, 108-120, 2019. Available from: $<$ http://dx.doi.org/10.1007/s12161-018-1343-6>. Accessed: Jan. 7, 2019. doi: 10.1007/s12161-018-1343-6.

IARD. International Alliance for Responsible Drinking Available from: <http://www.iard.org/policy-tables/drinkingguidelines-general-population/>. Accessed: Jun. 12, 2018.

IBGE. Brazilian Institute of Geography and Statistics. 2011 Available from: <https://ww2.ibge.gov.br/home/>. Accessed: Nov. $27,2018$.

JENDRAL, J. A. et al. Formaldehyde in alcoholic beverages: Large chemical survey using purpald screening followed by chromotropic acid spectrophotometry with multivariate curve resolution, International Journal of Analytical Chemistry, 2011, Article ID 797604. Available from: <https://doi.org/10.1155/2011/797604>. Accessed: Jul. 12, 2018. doi: 10.1155/2011/797604.

JEONG, HS. et al. Validation and determination of the contents of acetaldehyde and formaldehyde in foods. Toxicological Research, v.31, p.73-278, 2015. Available from: <https://doi.org/10.5487/ TR.2015.31.3.273>. Accessed: Jul. 12, 2018. doi: 10.5487/ TR.2015.31.3.273.

JECFA. Joint FAO/WHO Expert Committee on Food Additives, 2000. Available from: $<\mathrm{http} / /$ apps.who.int/food-additives-contaminantsjecfa-database/chemical.aspx?chemID=3695>. Accessed: Mar. 20, 2018.

KÄCHELE, M. et al. NMR investigation of acrolein stability in hydroalcoholic solution as a foundation for the valid HS-SPME/
GC-MS quantification of the unsaturatedaldehyde in beverages. Analytica Chimica Acta, 2014, 820, 112. Available from: <https:// doi.org/10.1016/j.aca.2014.02.030>. Accessed: Jul. 12, 2018. doi: 10.1016/j.aca.2014.02.030.

KENNISON, K. R. et al. Smoke-derived taint in wine: effect of postharvest smoke exposure of grapes on the chemical composition and sensory characteristics of wine, Journal of Agricultural and Food Chemistry, v.55, p.10897, 2007. Available from: <https:// doi.org/10.1021/jf072509k>. Accessed: Jul. 12, 2018. doi: $10.1021 / \mathrm{jf} 072509 \mathrm{k}$

LAGO, L. O. et al. Influence of ripeness and maceration of the grapes on levels of furan and carbonyl compounds in wineSimultaneous quantitative determination and assessment of the exposure risk to these compounds, Food Chemistry, v.230, p.594-603, 2017. Available from: <https://doi.org/10.1016/j. foodchem.2017.03.090>. Accessed: Jul. 12, 2018. doi: 10.1016/j. foodchem.2017.03.090

LACHENMEIER, D.W., et al. Carcinogenicity of acetaldehyde in alcoholic beverages: risk assessment outside ethanol metabolism. Addiction, v.104, p.533-550, 2009. Available from: $<$ https://doi.org/10.1111/j.1360-0443.2009.02516.x>. Accessed: Nov. 27, 2018

LIU, H. et al. Ethyl carbamate induces cell death through its effects on multiple metabolic pathways. Chemico-Biological Interactions, v.277, p.21-32, 2017. Available from: <https:/www.sciencedirect. com/science/article/pii/S0009279717304520?via\%3Dihub>. Accessed: May, 14, 2018. doi: 10.1016/j.cbi.2017.08.008.

MONAKHOVA, Y.B. et al. The margin of exposure to formaldehyde in alcoholic beverages. Archives of Industrial Hygiene and Toxicology, v.63, p.227-237, 2012. Available from: $<$ https://doi.org/10.2478/10004-1254-63-2012-2201>. Accessed: Nov. 27, 2018.

OSMAN, A.S. et al. Carvedilol can attenuate histamine-induced paw edema and formaldehyde-induced arthritis in rats without risk of gastric irritation. International Immunopharmacology, v.50, p.243-250, 2017. Available from: <https://doi.org/10.1016/j. intimp.2017.07.004>. Accessed: May, 14, 2018.

PERESTRELO, R. et al. Comprehensive two-dimensional gas chromatography with time-of-flight mass spectrometry combined with solid phase microextraction as a powerful tool for quantification of ethyl carbamate in fortified wines. The case study of Madeira wine, Journal of Chromatography, v.1217, p.3441-3445, 2010. Available from: <https://doi.org/10.1016/j. chroma.2010.03.027>. Accessed: Accessed: Jul. 12, 2018. doi: 10.1016/j.chroma.2010.03.027.

RIBÉREAU-GAYON, D. et al. Handbook of Enology: The Microbiology of Wine and Vinifications. 2nd ed., John Wiley \& Sons Ltd, England, 2006.

SACHSE, B.et al. Bioactivation of food genotoxicants 5-hydroxymethylfurfural and furfuryl alcohol by sulfotransferases from human, mouse and rat: a comparative study. Archives of Toxicology, v.90, n.1, p.137-48, 2016. Available from: <https:// link.springer.com/article/10.1007\%2Fs00204-014-1392-6>. Accessed: May, 14, 2018. doi: 10.1007/s00204-014-1392-6.

SCHLATTER, J.et al. Application of the margin of exposure (MOE) approach to substances in food that are genotoxic and

Ciência Rural, v.49, n.3, 2019. 
carcinogenic Example: Ethyl carbamate. Food and Chemical Toxicology, v.48, p.S63-S68, 2010. Available from: $<$ http://dx.doi. org/10.1016/j.fct.2009.10.032. Accessed: Nov. 27, 2018.

VÁZQUEZ-AGELL, M. et al. Inflammatory markers of atherosclerosis are decreased after moderate consumption of Cava (sparkling wine) in men with low cardiovascular risk. The Journal of Nutrition, v.137, n.10, p.2279-2284, 2007. Available from: <https://doi.org/10.1093/jn/137.10.2279>. Accessed: May, 14, 2018. doi: 10.1093/jn/137.10.227.

WEBBER, V.et al. Effect of glutathione during bottle storage of sparkling wine. Food Chemistry, v.216, p.254-259, 2017. Available from: <http://dx.doi.org/10.1016/j.foodchem.2016.08.042>. Accessed: Jul. 12, 2018. doi: 10.1016/j.foodchem.2016.08.042.

World Health Organization (WHO), Human Health Risk Assessment Toolkit: Chemical, 2010. Available from: <http:// www.who.int/ipcs/methods/harmonization/areas/ra_toolkit/en/>. Accessed: Jun. 12, 2018

ZHANG, J. et al. Simultaneous determination of ethyl carbamate and urea in alcoholic beverages by high-performance liquid chromatography coupled with fluorescence detection. Journal of Agricultural and Food Chemistry, v.62, p.2797, 2014. Available from: <https://doi. org/10.1021/jf405400y>. Accessed: Jul. 12, 2018. doi: 10.1021/jf4054. 